\title{
Why Do Students Expect to Stay Longer in College? Evidence from Europe
}

by

\author{
Giorgio Brunello \\ Rudolf Winter-Ebmer *) \\ Working Paper No. 0210 \\ August 2002
}

Johannes Kepler University of Linz Department of Economics Altenberger Strasse 69 A-4040 Linz - Auhof, Austria rudolf.winterebmer@jku.at phone +43 (0)70 $2468-8236$ 


\title{
Why Do Students Expect to Stay Longer in College? Evidence from Europe
}

\author{
Giorgio Brunello \\ (Padova, CESifo and IZA) \\ Rudolf Winter-Ebmer
}

(Linz, CEPR, IZA and WIFO)*

August, 2002

\begin{abstract}
:
We investigate the expected college completion time of European college students by using data from a survey of more than 3000 students in 10 countries. We explain observed excess time to graduation by paying special attention to labor market variables, such as unemployment, wage differentials and employment protection, and to the funding of tertiary education.

JEL: I20, I22.

Keywords: College completion, wage inequality, college, expectations.

\section{* Corresponding author}

This research was supported by the European Commission under the TSER program PL980182 for the PuRe project. Thanks to Claudio Lucifora for very helpful discussions and comments. We are grateful to M. Arai, R. Asplund, J. Bacher, C. Badelt, R. Böheim, J. Brüderl, W. Buchholz, M. Burda, D. Checchi, K. Denny, B. Fitzenberger, K. Gerlach, H. Karcher, P. Ordine, P. Pereira, A. Skalli, P. Tsakloglou, V. Ulrich, P. Welzel, N. Westergard-Nielsen, S. Wolter, R. Wright and J. Zweimüller for help in administrating the survey in the different countries. The usual disclaimer applies.
\end{abstract}




\section{Introduction}

In a number of European countries students take longer than required to complete college. According to the OECD [1998], median graduation age in 1998 for short first degrees (typically three years) was as high as 27.6 in Denmark and 25.7 in Sweden. For longer degrees (typically 4 years) median graduation age was 27.4 in Austria and 26.8 in Italy.

Longer than required time to graduation can affect available resources per student and often postpones the delicate process of transition from full time education to the labor market, thereby reducing labor supply and tax revenues (Hakkinen and Uusitalo [2002]).

Later completion can be due to exogenous events after enrolment or can be the result of individual choice. In a survey conducted by the authors on the earnings expectations of more than 3000 Economics and Business college students in 10 European countries ${ }^{1}$, we find that the percentage of students expecting to complete their degree at least one year later than the required time ranges from $31.2 \%$ in Sweden and $30.8 \%$ in Italy to close to zero in the UK and Ireland. While Swiss and Portuguese students are close to the Anglo-Saxon pattern (3.5\% and $4.6 \%$ respectively), French and German students lie in between these extremes (17.1\% and $10 \%$ respectively).

How do we explain this variation? Most available research on duration of college studies concentrates on financial aid to students (Booth and Satchell [1995], Ehrenberg and Mavros [1995], Hakkinen and Uusitalo [2002]), on the one hand, and on individual ability, on the other hand ( Arulampalam et al. [2002], Hackl and Sedlacek [2002], Van Ours and Ridder [2002], Löfgren and Ohlsson [1999]). This research looks at national experiences and has little to say on cross-country variations in expected time to graduation.

In this paper we try to account for these variations by emphasizing differences in labor market variables, including the unemployment rate of college graduates and the college wage gap, and in labor market institutions. We also consider the role played by college quality and by differences in the public versus private financing of college education.

\footnotetext{
${ }^{1}$ See Brunello, Lucifora and Winter Ebmer (2002) for details of the survey.
} 


\section{The Data and the Empirical Strategy}

The survey was conducted in 26 economics and business faculties belonging to universities distributed across 10 European countries ${ }^{2}$. The questionnaire was distributed to college undergraduates during the academic year 1999/2000. These undergraduates are enrolled in their first, second or third year if the degree lasts three years and also in their fourth year if the degree lasts one year longer. Overall, 3,382 questionnaires were filled in. Students were asked to state the year when they expected to finish their college (first degree). We combine this information with the public information on the required minimum number of years needed to complete a degree, by country, to compute $Y$, the expected excess number of years to completion. It turns out that average excess years range from 0.047 in the United Kingdom to 1.200 in Italy.

Given the preponderance of zeros and of small values, we treat the observations as count data and use the following Poisson model (see Greene [1990])

$$
\operatorname{Prob}\left(Y_{i}=y_{i}\right)=\frac{e^{-\lambda_{i}} \lambda_{i}^{y_{i}}}{y_{i} !} \quad y_{i}=0,1,2, \ldots
$$

where $\lambda$ is the conditional mean and variance ${ }^{3}$ and

$$
\ln \lambda_{i}=\beta^{\prime} x_{i}
$$

The vector $x$ includes college dummies, the interaction of these dummies with a gender dummy, individual age, information on family background (whether parents hold a university degree; whether the student is in the same major as one or both of the parents; the individual discount rate, estimated by offering to each student the choice between a monetary windfall today and a higher windfall in one year time; a dummy for students enrolled in their third or fourth year; a self assessed measure of ability (relative to colleague students, (0-6) with increasing ability); tuition costs in Euros; two dummies on the sources of information about future labor market prospects (for information drawn from public sources and for information drawn from personal sources); six dummies capturing the reason for the college choice (distance; college reputation; tuition and housing costs; income and job prospects; assignment by some national rule; interest in the field);

\footnotetext{
${ }^{2}$ Austria, Denmark, France, Germany, Ireland, Italy, Portugal, Sweden, Switzerland and the UK.

${ }^{3}$ We find that allowing for different mean and variance, as in the Negative Binomial model, does not help in explaining the data any better.
} 
the number of working hours during college; an estimate of expected future job prospects and the expected college wage gap, computed as the percentage difference between the expected college wage and the expected high school wage, defined as the wage that students expect to earn in the event of starting work just after high school. Figure 1 shows the delay in college completion: most students expect to finish on time or take one year longer. The data are fitted to a Poisson model with the aforementioned variables. The fit of the model is very good and gives a remarkable approximation to the observed proportions.

With the plausible exception of college dummies and their interactions, family background variables and the individual discount rate, the variables included in the vector $x$ are likely to be endogenous. In the absence of an obvious instrumental variables strategy, we estimate three versions of [1], a parsimonious version which excludes all potentially endogenous variables (column (1) of Table 1), a similar specification with the addition of the enrolment dummy for year 3 and 4 (column (2) in the table) and a specification which includes all the variables in the vector $x$ (column (3)).

The table shows that the expected excess number of years to completion is higher for older students who are enrolled in their third or fourth year. While working at college does not affect students' expectations, excess years are significantly shorter among students who expect a higher college wage gap. Interestingly, students who enrolled in an institution because of its reputation expect to study significantly longer.

\section{Cross country differences in expected excess duration}

Table 1 does not include the coefficients associated to the college dummies and to their interactions with the gender dummy. These coefficients capture cross-college and cross-country differences in expected excess years to graduation, and how these differences vary by gender. We retrieve these coefficients and use them as the dependent variable in a second stage regression which relates these coefficients to a set of college and labor market variables that vary by country and/or by country and gender.

These variables include the 1999 unemployment rate of college graduates, by country and gender (source: OECD); the 1996 college wage gap, by country and gender (sources: European Community Household Panel wave 1997, for all countries but Switzerland; national sources for Switzerland); the 1995-1999 average rate of growth, by country (source: OECD); the 1999 public share of expenditure on tertiary education (source: OECD); the employment protection index in 1995 (source: Nickell and Nunziata [2001]), by country; a $(0,1)$ dummy for college quality, based 
on the assessment of the PuRe team of experts ${ }^{4}$, by college and country; and a $(0,1)$ dummy indicating whether the college is private.

We use weighted least squares, with the inverse values of the variances of the coefficients estimated in the first stage as weights. Since we have three different specifications for the first stage, we replicate the exercise for each set of estimated college dummies. Our results are in Table 2.

Columns (1) and (1a) in the table refer to the first stage specification, which includes only strictly exogenous variables, and differ because of the exclusion of college unemployment in the latter column. The remaining columns refer to the alternative first stage specifications. We find that average college specific excess time to completion is higher the higher is the national unemployment rate for college graduates and the lower is the country - specific observed college wage gap ${ }^{5}$. While the former effect is not always precisely estimated, the latter effect is quite precise. Therefore, wage compression by education reduces the incentives to complete education in time by narrowing the gap between expected benefits and opportunity $\operatorname{costs}^{6}$. On the other hand, a higher unemployment rate for graduates reduces the incentives to graduate early, because of the poorer labor market prospects. We also find that the aggregate growth rate in the economy- in the five years prior to the survey - has a positive impact on the expected time to graduation. This effect, however, is barely significant in one column out of six.

Excess time to graduation is significantly higher, on average, in countries where the share of public expenditure on total expenditure for tertiary education is higher. This is consistent with human capital theory, which suggests that the investment in years of education depends on the comparison of marginal benefits with marginal costs. A higher share of public expenditure reduces private marginal costs and therefore leads, ceteris paribus, to longer years in college. This negative effect is not often stressed in the literature, which usually emphasizes the importance of public funding to incite the enrolment of liquidity constrained individuals.

Excess time to graduation is also substantially higher in countries with stricter employment protection. Employment protection reduces layoffs and hirings, with uncertain effects on average employment (Bertola [1999]). One negative side effect of higher employment protection which has not been stressed much in the literature is that it could reduce the incentive to graduate early, because of the more difficult transition from school to work.

\footnotetext{
${ }^{4}$ The team covering 15 European countries was funded by the European Commission TSER project PL980182 on the private returns to education (PuRe).

${ }_{5}^{5}$ Note that the results remains the same even when we control for individually expected college wag gaps, as in Col. (3) of Table 2.

${ }^{6}$ We also experimented with the inclusion of the difference between the regional and the national wage gap, which was never significant, as one would expect in the relatively mobile college labor market.
} 
Graduation from colleges perceived to be of higher quality takes longer, perhaps because of the more demanding curriculum. There is also some evidence suggesting that students enrolled in private colleges take longer to graduate. This is consistent with the fact that many private colleges in Europe are of relatively lower quality than public colleges, and attract as a consequence students of inferior quality ${ }^{7}$.

Broadly speaking, the results remain unaltered when we consider the remaining columns of Table 2, where we use the coefficients estimated in less parsimonious first stage specifications.

\section{Conclusions}

We have found significant positive correlations between cross-country and cross-college differences in expected time to graduation, the degree of employment protection and the public share of expenditure for college education. Stricter employment protection not only reduces hirings but has the undesirable supply side effect of increasing expected time to college graduation. On the other hand, a higher share of public expenditure helps in limiting the negative enrolment effects of liquidity constraints at the price of delaying expected college completion.

Perceived college quality matters, and the higher the quality the later expected completion. Last but not least, students in countries with a higher college wage gap expect to complete earlier their college degree in economics and business. Therefore, a somewhat unappealing consequence of wage compression is that it might reduce the incentive to complete college in time.

\footnotetext{
${ }^{7}$ Brunello, Lucifora and Winter Ebmer (2001) find that students in private colleges have significantly lower wage expectations than their peers in private universities.
} 


\section{References}

Arulampalam, Wiji, Naylor, Robin A. and Jeremy P. Smith (2002), Effects of In-class Variation and Student Rank on the Probability of Withdrawal: Cross-section and Time-series Analysis for UK University Students, mimeo, University of Warwick.

Bertola, Guiseppe, Microeconomic Perspectives on Aggregate Labor Markets, in Ashenfelter, O. and Card, David (1999), Handbook of Labor Economics, North - Holland, Amsterdam.,

Booth, Alison L. and Stephen E. Satchell (1995), The Hazards of Doing a Ph.D: An Analysis of Completion and Withdrawal Rates of British Ph.D. Students in the 1980s, Journal of the Royal Statistical Society A 158, 2, 297-318.

Brunello, Giorgio, Lucifora, Claudio and Rudolf Winter-Ebmer (2002), The Wage Expectations of European Business and Economics Students, mimeo, University of Linz.

Ehrenberg, Ronald G. and Panagiotis Mavros (1995), Do Doctoral Students' Financial Support Patterns Affect Their Times-to-Degree and Completion Probabilities, The Journal of Human Resources 30, 3, 581-609.

Hackl, Peter and G. Sedlacek (2002), Studienverlaufsanalyse, mimeo, Vienna University of Business and Economics.

Hakkinen, Iida and Roope Uusitalo (2002), The Effect of Student Aid Reform on Graduation Times, A Duration Analysis, mimeo, Uppsala University.

Löfgren, Curt and Henry Ohlsson (1999), What Determines When Undergraduates Complete Their Theses? Evidence From Two Economics Departments, Economics of Education Review 18, 79-988.

Nickell, Stephen, and Nunziata, Luca, (2001), Labor Market Institutions Database, Oxford Institute of Economics and Statistics.

OECD (1998), Education at a Glance, Paris.

Siegfried, John J. and Wendy Stock (2001), So You Want to Earn a Ph.D. in Economics? How Long Do You Think it Will Take?, The Journal of Human Resources 36, 2, 364-378

Van Ours, Jan and Geert Ridder (2002), Fast Track or Failure: A Study of the Completion Rates of Graduate Students in Economics, Economics of Education Review, forthcoming. 
Table 1: Excess College Duration

\begin{tabular}{|c|c|c|c|}
\hline & (1) & (2) & (3) \\
\hline Age (years) & $\begin{array}{c}0.057 \\
(0.016)^{* *}\end{array}$ & $\begin{array}{c}0.029 \\
(0.014)^{*}\end{array}$ & $\begin{array}{l}0.021 \\
(0.014)\end{array}$ \\
\hline Parents college educated $(0,2)$ & $\begin{array}{l}0.016 \\
(0.056)\end{array}$ & $\begin{array}{l}0.008 \\
(0.054)\end{array}$ & $\begin{array}{l}0.019 \\
(0.072)\end{array}$ \\
\hline Parents same field $(0,2)$ & $\begin{array}{l}-0.025 \\
(0.043)\end{array}$ & $\begin{array}{l}-0.031 \\
(0.038)\end{array}$ & $\begin{array}{l}-0.074 \\
(0.036)^{*}\end{array}$ \\
\hline Discount rate (\%) & $\begin{array}{l}0.644 \\
(0.537)\end{array}$ & $\begin{array}{l}0.601 \\
(0.594)\end{array}$ & $\begin{array}{l}0.853 \\
(0.562)\end{array}$ \\
\hline Enrolled in $3^{\text {rd }}, 4^{\text {th }}$ year & & $\begin{array}{c}0.703 \\
(0.114)^{* *}\end{array}$ & $\begin{array}{c}0.674 \\
(0.129)^{* *}\end{array}$ \\
\hline Information public sources $(0,1)$ & & & $\begin{array}{l}-0.015 \\
(0.023)\end{array}$ \\
\hline Information personal sources. $(0,1)$ & & & $\begin{array}{l}0.054 \\
(0.044)\end{array}$ \\
\hline Reason select school : distance $(0,1)$ & & & $\begin{array}{l}0.026 \\
(0.115)\end{array}$ \\
\hline ---: reputation $(0,1)$ & & & $\begin{array}{c}0.207 \\
(0.048)^{* *}\end{array}$ \\
\hline ---: costs $(0,1)$ & & & $\begin{array}{l}0.025 \\
(0.091)\end{array}$ \\
\hline ---: income $(0,1)$ & & & $\begin{array}{l}0.052 \\
(0.077)\end{array}$ \\
\hline ---: assignment $(0,1)$ & & & $\begin{array}{l}0.061 \\
(0.056)\end{array}$ \\
\hline ---: interest in subject $(0,1)$ & & & $\begin{array}{l}-0.001 \\
(0.048)\end{array}$ \\
\hline Relative performance $(0-6)$ & & & $\begin{array}{l}-0.079 \\
(0.041)\end{array}$ \\
\hline Direct college costs & & & $\begin{array}{l}0.024 \\
(0.045)\end{array}$ \\
\hline Hours of work/week & & & $\begin{array}{l}0.001 \\
(0.002)\end{array}$ \\
\hline Exp. job prospects after graduation & & & $\begin{array}{l}-0.009 \\
(0.033)\end{array}$ \\
\hline Expected college-H.S. wage gap & & & $\begin{array}{c}-0.052 \\
(0.014)^{* *}\end{array}$ \\
\hline Observations & 3098 & 3098 & 2747 \\
\hline $\log \mathrm{L}$ & -3007.2 & -2943.9 & -2596.3 \\
\hline
\end{tabular}

Robust standard errors in parentheses

$*$ significant at 5\%; ** significant at $1 \%$ 
Table 2: Excess college duration: cross-country institutions

\begin{tabular}{lccc|ccc}
\hline & $(\mathbf{1})$ & $\mathbf{( 2 )}$ & $\mathbf{( 3 )}$ & $\mathbf{( 1 a )}$ & $\mathbf{( 2 a )}$ & $\mathbf{( 3 a )}$ \\
\hline Unemployment rate & 0.105 & $0.140 \sim$ & $0.137 \sim$ & & & \\
for college graduates & $(0.076)$ & $(0.058)$ & $(0.069)$ & & & \\
College wage gap. & $-1.134^{*}$ & $-1.064^{*}$ & $-1.647^{*}$ & $-1.224^{*}$ & $-1.167^{*}$ & $-1.716^{*}$ \\
& $(0.240)$ & $(0.279)$ & $(0.306)$ & $(0.260)$ & $(0.296)$ & $(0.379)$ \\
Growth rate 95-99 & $0.104 \sim$ & 0.070 & 0.079 & 0.095 & 0.061 & 0.059 \\
& $(0.051)$ & $(0.052)$ & $(0.077)$ & $(0.053)$ & $(0.056)$ & $(0.086)$ \\
Public share of & $0.055^{*}$ & $0.064^{*}$ & $0.061^{*}$ & $0.051^{*}$ & $0.058^{*}$ & $0.055^{*}$ \\
expenditure higher edu. & $(0.012)$ & $(0.010)$ & $(0.012)$ & $(0.011)$ & $(0.010)$ & $(0.013)$ \\
& & & & & & \\
Employment protection & $1.293^{*}$ & $0.850^{*}$ & $1.131^{*}$ & $1.468^{*}$ & $1.083^{*}$ & $1.327^{*}$ \\
& $(0.342)$ & $(0.308)$ & $(0.329)$ & $(0.321)$ & $(0.309)$ & $(0.344)$ \\
Quality of college & $-0.381^{*}$ & $-0.332^{*}$ & -0.047 & $-0.372^{*}$ & $-0.307^{*}$ & -0.029 \\
& $(0.086)$ & $(0.113)$ & $(0.186)$ & $(0.080)$ & $(0.110)$ & $(0.174)$ \\
Private college dummy & $0.579 \sim$ & 0.638 & -0.023 & $0.588 \sim$ & 0.674 & 0.007 \\
& $(0.258)$ & $(0.338)$ & $(0.489)$ & $(0.246)$ & $(0.344)$ & $(0.461)$ \\
\hline Observations & 51 & 51 & 50 & 51 & 51 & 50 \\
R-squared & 0.739 & 0.694 & 0.613 & 0.73 & 0.675 & 0.595 \\
\hline
\end{tabular}

Rows (1) to (3) relate to respective rows in Table 1.

Robust standard errors in parentheses

$\sim(*, * *)$ significant at $10(5,1) \%$. 
Figure 1: Delay in College Completion: Observed Proportions and Poisson Model Prediction

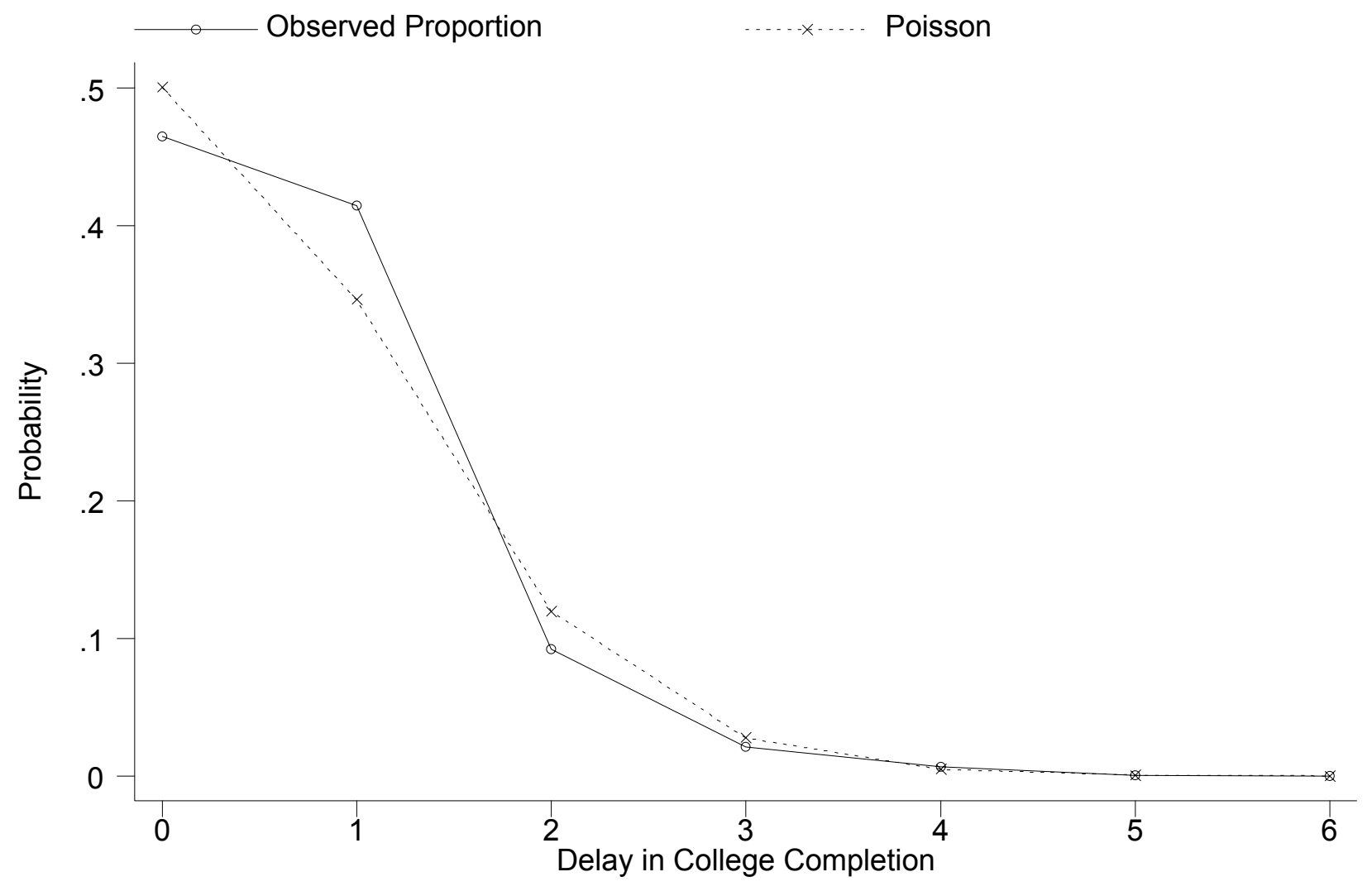

